\author{
선천성 중이 진주종의 육안적 소견을 \\ 중심으로 본 임상적 분석 \\ 아주대학교 의과대학 이비인후과학교실 \\ 박기현 · 양해동 · 전영명 · 박홍준
}

\title{
Congenital Middle Ear Cholesteatoma : A Clinical and Gross Pathological Review
}

\author{
Keehyun Park, MD, Hae-Dong Yang, MD, Young-Myoung Chun, MD and Hong-Joon Park, MD \\ Department of Otolaryngology, Ajou University School of Medicine, Suwon, Korea
}

\section{- ABSTRACT -}

Background and Objectives : Gross-pathologically, there are two types of congenital middle ear cholesteatoma : a closed keratotic cyst and an open matrix. This study aimed to analyze clinical characteristics of each pathologic type of congenital cholesteatoma and to facilitate better understanding of its pathogenesis. Materials and Method : We reviewed retrospectively 21 patients seen in the past 6 years between May 1994 to April 2000 who were diagnosed as congenital middle ear cholesteatoma under its definite criteria. This study was done by analyzing the patients' history, drum finding, temporal bone CT finding, operative finding and pathologic finding. Results : The open type congenital cholesteatoma which usually originated from posterosuperior quadrant of the mesotympanum showed higher degree of hearing loss and more frequent unusual presentation, and detected at an older age than the closed type congenital cholesteatoma. Conclusion : The pathogenesis of open type congenital cholesteatoma may be different from that of closed type congenital cholesteatoma. (J Clinical Otolaryngol 2000;11:249-255)

KEY WORDS : Open type congenital cholesteatoma $\cdot$ Closed type congenital cholesteatoma $\cdot$ Pathogenesis.

\section{서 론}

중이강에 발생하는 선천성 진주종은 일반적으로 정상 고막의 내측에서 발견되는 회백색의 표피 봉입체의 병 리 조직 소견으로 진단된다. 전체 진주종 환자의 2 5\% 정도 차지할 정도로 비교적 드문 질환으로 생각되어져

논문접수일 : 2000년 8월 25일

심사완료일 : 2000년 11월 5일

교신저자 : 박기현, 442- 749 경기도 수원시 팔달구 원천동

산 5번지 아주대학교 의과대학 이비인후과학교실

전화 : (031) 219- 5265. 전송 : (031) 219- 5264

E-mail : parkkh@madang.ajou.ac.kr
왔으나 최근 20년 동안에 발견율이 현저히 증가되어 국 내외 여러 연구기관에서 많은 수의 증례를 분석하여 보 고하고 있다. ${ }^{1-6)}$

많은 연구자들이 선천성 진주종의 발병기전에 대하여 연구하여 왔으나, ${ }^{7-10)}$ 본 질환의 임상적인 한계성 때문 에 더 이상의 활발한 연구가 진행되지 못하였고 어느 가설도 본 질환의 발생을 완벽하게 설명하지 못하는 실 정이다.

지금까지 알려진 선천성 진주종의 발병기전 대표적인 네 가지 중 괄목할만한 것이 $\mathrm{Aimi}^{8)}$ 가 주장한 고실륜 결손설(lack of tympanic ring theory) 로 태생기에 고 실륜의 결손으로 외배엽세포의 이동이 억제되지 않아서 
고실협부에 선천성 진주종이 발생한다는 것이고, 또 다 른 하나가 Michaels ${ }^{10)}$ 이 주장한 표피양 형성설(epidermoid formation theory) 로 태생기에 고실륜의 전방 에 정상적으로 존재하는 외배엽세포들이 태생 33주 이 후에도 퇴화하지 않고 증식하여 표피양 형성을 하게 되 어 선천성 진주종을 형성하게 된다는 것이다. 발생위치에 대해서도 A imi는 고실의 후상방, Michaels은 고실의 전 상방이라고 주장하여 그 이견이 좁혀지지 않고 있다.

최근 McGill 등 ${ }^{4}$ 은 선천성 진주종의 육안적 병리 조직 소견을 폐쇄 낭형(closed cystic type) 과 개방 침습형 (open infiltrative type)의 두 가지 형태로 분류하였고, Soderberg 등 ${ }^{11)}$ 은 개방형( open type) 선천성 진주종 의 임상적 양상이 전형적인 형태의 선천성 진주종과는
다를 수 있다는 가능성을 제시하였다.

저자들은 선천성 중이 진주종의 두 가지 육안적 병리 조직학적 형태에 따른 임상적 특징을 분석하고 선천성 중이 진주종에 대한 앞으로의 병인 연구에 도움을 주고 자 본 연구를 시행하였다.

\section{재료 및 방법}

1994년 5월부터 2000년 4월까지 최근 6년간 아주 대학교병원 이비인후과에서 저자들에게 수술적 치료를 받고 병리조직학적으로 확진된 21명의 선천성 중이 진 주종 환자를 대상으로 본 연구를 시행하였다. 선천성 중 이 진주종에 대한 진단기준은 Derlacki와 Clemis ${ }^{12)}$ 의
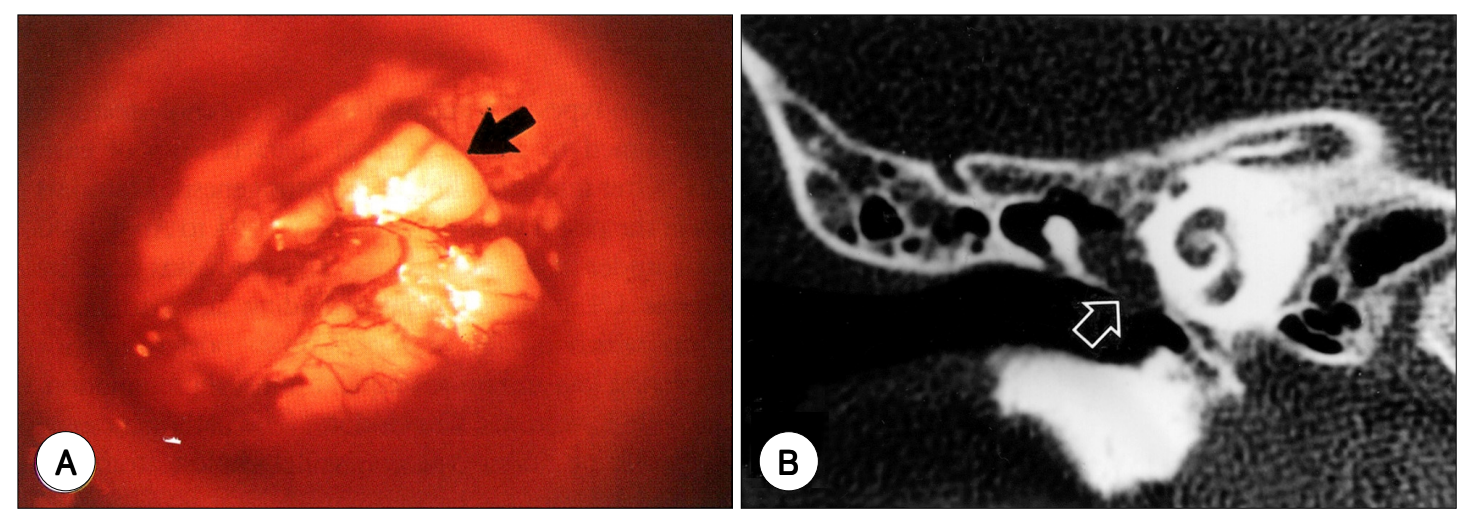

Fig. 1. Closed type congenital middle ear cholesteatoma. A : Operative finding: Whitish cholesteatoma (arrow) is seen just anterior to malleus handle. B : Temporal bone CT coronal view : Cyst-like soft tissue mass ( arrow) is seen at anterior mesotympanum.
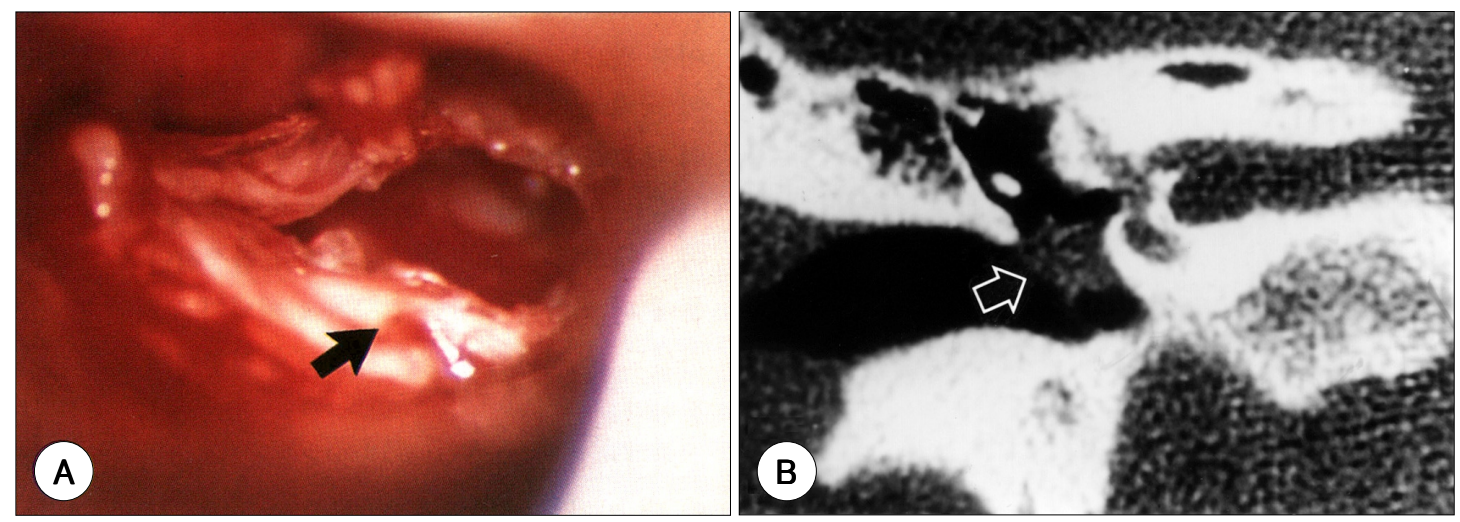

Fig. 2. Open type congenital middle ear cholesteatoma. A : Operative finding : Diffuse cholesteatoma mass ( arrow) is seen posterior to malleus handle. B : Temporal bone CT coronal view : Irregular shaped soft tissue mass ( arrow) is seen at posterior mesotympanum. 
박기현 외 : 선천성 중이 진주종의 임상적 분석

기준을 조금 수정한 Levenson 등 $^{13)}$ 의 기준을 이용하 였다. 환자들의 연령분포는 4 세에서 36 세까지로 평균연 령은 15.6세였다. 남녀비는 14대 7 로 남자 환자가 두 배 정도 더 많았다.

환자들의 병력, 고막소견, 측두골 전산화 단층 촬영 소 견, 수술 소견 및 육안적 병리 소견을 참조로 하여 본 연 구를 시행하였다. 폐쇄형(closed type) 과 개방형( open ty pe) 에 대한 구분은 T akeda 등 ${ }^{14)}$ 의 기준을 따랐는데, 완전한 각질의 낭을 형성한 경우를 폐쇄형 선천성 중이 진주종(Fig. 1)으로 분류하였고 진주종 기질에 의해 중 이 점막이 일부 덮여 있는 경우를 개방형 선천성 중이 진 주종(Fig. 2)으로 분류하였다.

\section{결 과}

총 21례 중 폐쇄형이 9례, 개방형이 12례로 개방형 이 더 많았다. 진단 당시 나이를 보면, 개방형이 평균 18.8세(10세에서 34세까지 분포) 로 평균 11.4세(4세 에서 36세까지 분포) 의 폐쇄형보다 더 늦은 나이에서 발 견되었다 (T able 1).

선천성 진주종이 발견된 위치를 대략적으로 보면 폐쇄 형에서는 총 9 례 중 7 례에서 중이강의 전상방에 위치 하였고 나머지 2례는 중이강의 후상방에 위치하였다. 이 에 반해서 개방형에서는 총 12 례 중 11례에서 중이강의 후상방에 위치하였고 1례에서만 중이강의 전상방에 위 치하였다 (T able 2).

진단 당시 청력소실의 정도를 보면 폐쇄형에서는 정 상 청력을 보인 경우가 2 례, 경도의 청력소실을 보인 경 우가 4례, 중등도 이상의 청력소실을 보인 경우가 3례 있었으며 평균 $35 \mathrm{~dB}$ 의 청력소실을 보였다. 개방형에서 는 정상청력을 보인 경우는 없었으며 경도의 청력소실 을 보인 경우가 3 례, 중등도 이상의 청력소실을 보인 경 우가 9 례 있었으며 평균 $51 \mathrm{~dB}$ 의 청력소실을 보였다

Table 1. Types and age of patients with congenital cholesteatoma

\begin{tabular}{lcc} 
& Case & Age (range) \\
\hline Closed type & 9 & $11.4(4-36)$ years \\
Open type & 12 & $18.8(10-34)$ years \\
\hline Total & 21 & $15.6(4-36)$ years \\
\hline
\end{tabular}

( $\mathrm{T}$ able 3) .

일반적으로 보이는 선천성 중이 진주종의 소견과 달리 특이한 소견을 보인 경우를 살펴보면(Table 4), 청력 소실이 없이 우연히 발견된 경우가 폐쇄형에서 2례 있었 으며, 고막소견과 전산화 단층촬영소견에서 진주종이 관 찰되지 않고 시험적 고실 개방술 중에 진주종을 확인한 경우가 개방형에서 2례 있었다 Fig. 3). 그리고, 진주종 에 의해 외측 세반 고리관에 누공을 형성한 경우가 개방 형에서 3례 관찰되었다(Fig. 4).

선천성 진주종에 대한 수술은 폐쇄형에서는 총 9례 중 6례에서 고실절개술(tympanotomy approach)을 시행 하였고, 개방형에서는 총 12례 중 8례에서 유양동 삭개 술( mastoidectomy approach)을 시행하여 결과적으로 폐쇄형에서는 고실절개술을 더 많이 시행하였고, 개방형 에서는 유양동 삭개술을 더 많이 시행하였다( T able 5) 재수술을 시행한 경우는 폐쇄형 2례, 개방형 1례 해서 총 3례가 있었다.

Table 2. Site of congenital cholesteatoma ( cases)

\begin{tabular}{lccc}
\hline & ASQ & PSQ & Total \\
\hline Closed type & $7^{*}$ & $2^{\dagger}$ & 9 \\
Open type & $1^{\ddagger}$ & $11^{\S}$ & 12 \\
\hline Total & 8 & 13 & 21 \\
\hline ASQ : Anterosuperior quadrant of mesotympanum \\
PSQ : Posterosuperior quadrant of mesotympanum \\
$*:$ including 2 cases filling whole mesotympanum \\
$\dagger$ : including 1 case extending to aditus ad antrum \\
$\ddagger$ \\
$\S$ : including 1 case extending to epitympanum \\
$\S \quad$ : including 2 cases extending to aditus ad antrum
\end{tabular}

Table 3. Degree of hearing loss of patients with congenital cholesteatoma

\begin{tabular}{lccccc}
\hline & $\leq 26 \mathrm{~dB} 27-$ & $40 \mathrm{~dB}>40 \mathrm{~dB}$ & $\begin{array}{c}\text { Mean } \\
\text { (range) }\end{array}$ \\
\hline Closed type & $2^{*}$ & $4^{*}$ & $3^{*}$ & $35(10-55) \mathrm{dB}$ \\
Open type & $0^{*}$ & $3^{*}$ & $9^{*}$ & $51(30-70) \mathrm{dB}$ \\
\hline$*$ cases & & & & &
\end{tabular}

Table 4. Unusual presentations of patients with congenital cholesteatoma ( cases)

\begin{tabular}{lcc}
\hline & Closed type Open type \\
\hline No hearing loss & 2 & 0 \\
No mass behind intact drum & 0 & 2 \\
Present lateral SC fistula & 0 & 3 \\
\hline
\end{tabular}




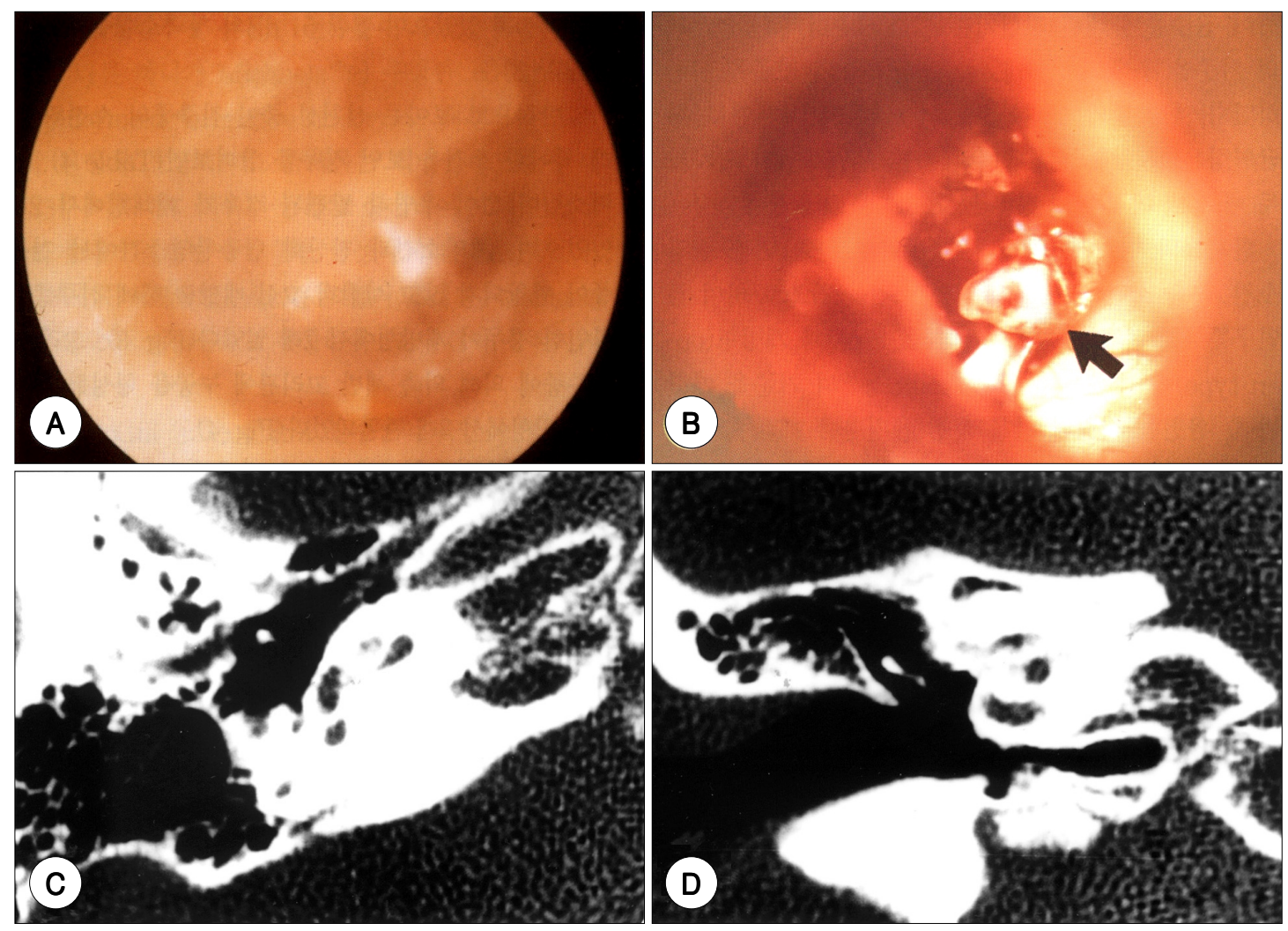

Fig. 3. The first case of unusual presentation : no mass behind intact drum. A : Myringoscopic finding : The eardrum appears normal. B : Operative finding: Small whitish diffuse type cholesteatoma (arrow) is noted around the incudostapedial joint. C : Temporal bone CT axial view : No abnormal mass is seen. D : Temporal bone CT coronal view : No abnormal mass is seen.

\section{고 찰}

이제까지 선천성 진주종의 발생기전은 상피 이형성 (Sade 등), ${ }^{7)}$ 고실륜의 결손 (A imi), ${ }^{8)}$ 양수내 상피세 포의 역류 (Northrop 등), ${ }^{9}$ 표피양 형성 (Michaels 등) ${ }^{10)}$ 이 제시되었으나, 어느 가설도 병인을 완전히 설명하지 는 못하고 있다.

Sade 등 $^{7)}$ 은 중이 점막이 염증에 의해서 상피세포로 이형성될 수 있다고 하였고 이러한 상피 이형성을 단순 만성 중이염 환자의 $40 \%$ 에서 확인하였다. 드물기는 하 지만 각질화도 존재하여 진주종의 원인을 제공할 수 있 다고 하였다.

$\mathrm{A} \mathrm{imi}^{8)}$ 는 선천성 진주종의 발생위치가 제 1 새궁과 제2
새궁의 접합부위, 즉 고실협부(tympanic isthmus) 와 밀접한 관계가 있음을 발견하고, 또한 태생기에 고실륜 (tympanic ring) 의 역할을 인식하게 되었다. 고실륜이 란 골부외이도를 형상하게 되는 고골(tympanic ring)의 초기 단계를 말하는 것으로, 이는 약 태생 10주경부터 제 1 새궁과 제 2 새궁의 접합부위에서 발견되어 외이도의 외배엽세포의 중이강내로의 이동을 억제하는 역할을 하게 된다. 태아의 조직연구 결과 16주 반 된 태아에서 고실 협부 부위에서 고실륜의 결손을 발견하게 되었으며, 외배 엽세포들이 고실협부 쪽으로 유두상 돌출을 하고 있음이 관찰되었다. 따라서 $\mathrm{A}$ imi는 고실륜의 결손으로 외배엽 세포의 이동이 억제되지 않아서 선천성 진주종이 발생한 다는 가설을 제안하였다.

Northrop 등 ${ }^{9}$ 은 신생아와 유아들의 측두골내에서 양 

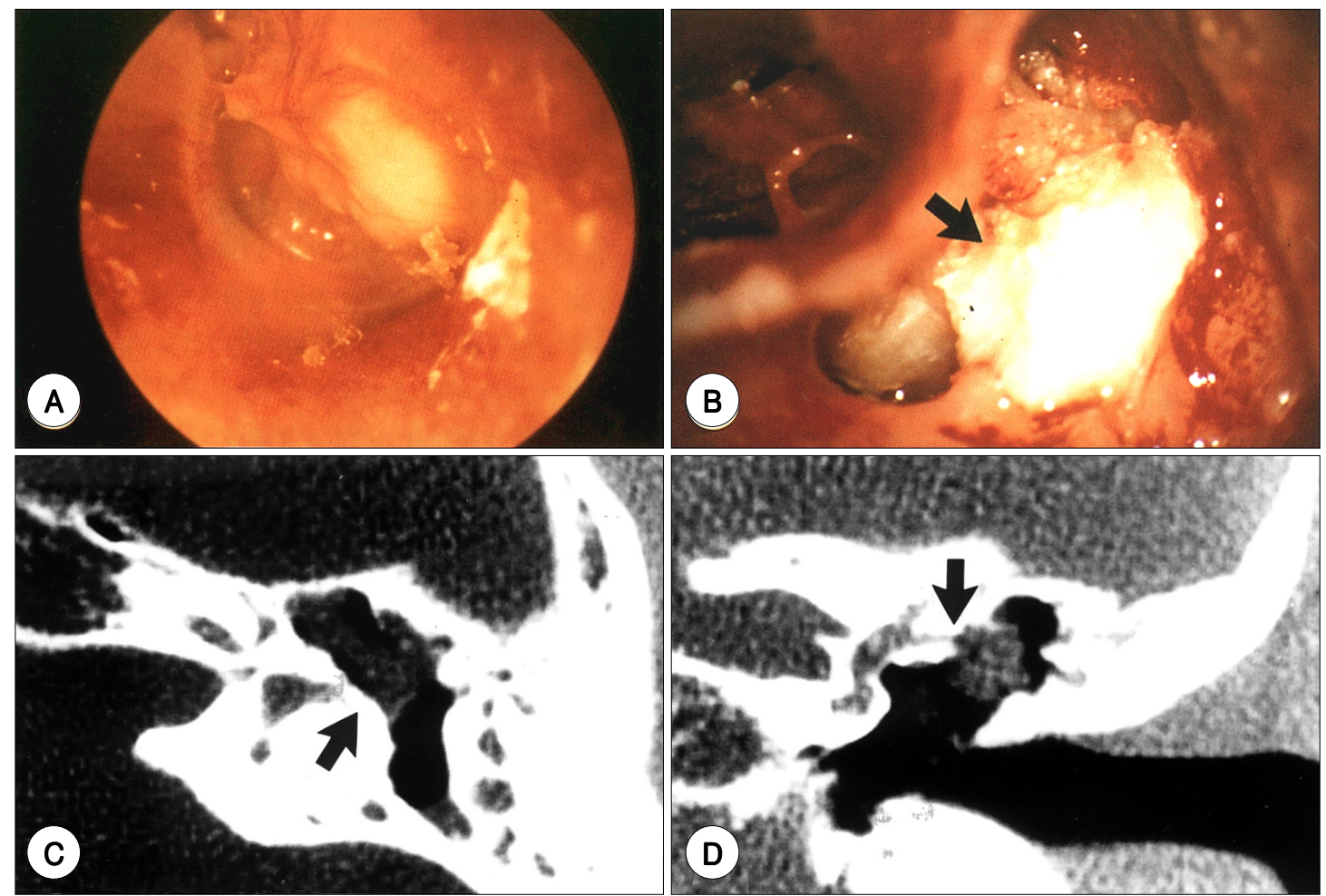

Fig. 4. The second case of unusual presentation : present lateral semicircular fistula. A : Myringoscopic finding : Whitish mass is seen at posterosuperior quadrant of the drum. B : Operative finding : Diffuse type cholesteatoma (arrow) is observed at mastoid antrum during intact canal wall mastoidectomy. C : Temporal bone CT axial view : Lateral semicircular canal fistula ( arrow) with diffuse type cholesteatoma mass is seen. D : Temporal bone CT coronal view : Diffuse type soft tissue density is seen at attic area and erodes the lateral end of the lateral semicircular canal ( arrow).

Table 5. Surgery of patients with congenital cholesteatoma( cases)

\begin{tabular}{lcc}
\hline & Closed type & Open type \\
\hline Tympanotomy & 6 & 4 \\
Mastoidectomy & 3 & 8 \\
\hline
\end{tabular}

수에서 기원한 상피세포들이 흔히 관찰되는 것을 발견하 고, 이러한 세포들이 이물질 반응(foreign body reaction) 과 같은 활발한 조직학적 변회를 유도하여 신생아 중이염, 선천성 진주종, 유착성 고막등을 일으킬 수 있다 고 생각하였다.

Michaels ${ }^{10)}$ 은 선천성 진주종이 발생중인 중이강내의 정상적으로 존재하는 외배엽 세포들에서 발생한다는 가 설을 발표하였고, 대부분의 태아에서 33주까지 이관과 중이강의 경계부위 즉 고실륜의 전방에 외배엽 세포들이 존재하는 것을 확인하였다. 이 외배엽 세포들은 태생 33
주 이후에는 정상적으로 퇴화하게 되어 있으나, 퇴화하 지 않고 증식하여 표피양 형성(epidermoid formation) 을 하게 되어 선천성 진주종을 형성하게 된다고 주장하 였다.

선천성 진주종의 발생 위치에 대한 연구를 살펴 보면, Friedberg $^{3)}$ 는 선천성 진주종은 정상적으로는 중이강의 전상방에서만 생기며 비교적 가벼운 외상에 의해 중이 강내 다른 곳으로 이동되어질 수 있다고 하였다. Michaels ${ }^{15)}$ 은 선천성 진주종의 위치는 원시 중배엽조직( $\mathrm{pr}-$ imitive mesenchyme)이 흡수되는 방식에 영향을 받 는다고 하였는데, 보통의 경우 원시 중배엽조직의 흡수 가 중이강의 전상방에서 먼저 일어나 하방으로 진행되 나 일부의 경우에서 전방보다 후방에서 원시 중배엽조 직의 흡수가 먼저 일어나게 되어 중이강의 전상방의 표 피양 형성( epidermoid formation) 으로부터 발달된 진 
주종이 후방쪽으로 급속히 밀려 나오게 되어 대부분의 진주종이 후방에 위치하게 되고 단지 가는 줄기에 의해 서 중이강의 전상방쪽에 부착하게 된다고 하였다. Levenson 등 ${ }^{13)}$ 은 중이강의 후방에서 생긴 선천성 진주종 은 중이강의 전방쪽에 있던 표피양 형성(epidermoid formation) 의 후방으로의 단순한 이동을 반영할 뿐이라 고 하였다.

전형적인 선천성 진주종은 폐쇄형으로 낭형이며 정상 고막 안쪽에서 진주빛의 종괴 형태로 존재하고 드물지 만 개방형의 존재에 대해서 McGill 등 ${ }^{4}$ 과 Michaels, ${ }^{15}$ 그리고 Cohen ${ }^{16)}$ 이 기술하였다. Michaels ${ }^{15)}$ 은 대부분 의 표피양 형성은 공모양의 표피양 세포들로 이루어져 이것이 자라나 폐쇄형의 각질화된 낭이 된다고 하였고 일부의 표피양 형성은 넓고 편평한 형태의 표면을 가져 개방형의 진주종을 형성한다고 하였다.

1998년 Soderberg 등 ${ }^{11)}$ 은 10례의 선천성 중이 진주 종에 대한 연구에서 개방형 선천성 진주종의 임상양상 이 폐쇄형과 다를 수 있다는 가능성을 확인하였다. 그가 보고한 10례 중 폐쇄형이 7례, 개방형이 3례였고 병리 형태별 발생위치는 폐쇄형 7 례 중에서 중이강의 전상방 에 2례, 후상방에 1례가 발생하였으며 4례에서는 위치 가 명확하지 않았다. 이와는 대조적으로 개방형 3 례 모 두는 중이강의 후상방에 위치하였다. 발견당시 나이를 보면 폐쇄형이 평균 5 세인데 반해 개방형이 평균 19세 로 휠씬 늦은 나이에서 발병되었다. 그 외에도 두 군간 에 전산화 단층촬영 소견 및 임피던스 검사상에 차이가 있다고 하였다. 본 연구와는 달리 청력소실의 정도는 두 군간에 큰 차이가 없었다.

이제것 많은 연구들에서 선천성 중이 진주종이 주로 중 이강의 전상방에서 발견되었다고 보고되어 요즘은 Michaels $^{10}$ 의 표피양 형성설(epidermoid formation theory) 이 A imi ${ }^{8}$ 의 고실륜 결손설( lack of ty mpanic ring theory) 보다 더 설득력있게 받아 들여지고 있는 것 같 다. 심지어 Soderberg 등른 자신의 개방형 선천성 중 이 진주종 3례 모두가 중이강의 후상방에 위치하였다 고 보고하면서 이 둘의 연관성을 Michaels ${ }^{15}$ 의 주장을 인용하여 설명하려 하였다. 즉, 편평한 형태(flat ty pe) 의 표피양 형성( epidermoid formation) 을 가진 환자에 서 원시 중배엽조직(primitive mesenchyme)의 흡수가
중이강의 후상방에서 먼저 일어날 경우 원래 전상방의 표피양 형성에서 자라고 있던 진주종이 후상방쪽으로 밀 리게 되어 후상방에 위치하는 개방형의 진주종이 생기 게 된 것이라고 생각한 것이다. Soderberg 드이은 그 밖에도 두 가지 다른 가능성에 대해서도 언급하였는데 그 중 하나가 폐쇄형의 진주종이 터져서 개방형의 진주 종이 되면서 발생 위치의 변화가 생겼다는 것이고, 다른 하나는 개방형은 상피 이형성과 같은 다른 병리기전에 의해 생긴 것을 반영한다는 것이다.

저자들의 증례에서 보면 폐쇄형의 선천성 진주종이 주 로 중이강의 전상방에 위치하였는데 이것은 Michaels ${ }^{10)}$ 의 표피양 형성설에 부합하는 소견이고 개방형이 주로 후상방에 위치하였는데 이것은 $\mathrm{A} \mathrm{imi} i^{8)}$ 의 고실륜 결손설 에 부합하는 소견이었다. 발생위치 뿐만 아니라 폐쇄형 과 개방형은 많은 서로 다른 임상양상을 보인다는 것을 본 연구를 통해 확인할 수 있었다. 개방형에서 청력소실 의 정도가 더 심하였는데 개방형에서 폐쇄형보다 이소 골의 파괴가 더 심한 것으로 생각되었다. 또한 개방형에 서 고실절개술보다 유양동 삭개술을 더 많이 시행하였는 데, 이는 개방형에서 폐쇄형보다 침습범위가 더 넓고 골 파괴가 크다는 것을 간접적으로 보여주는 결과라고 생 각되었다.

결론적으로 폐쇄형의 선천성 중이 진주종에 비해서 개 방형의 선천성 중이 진주종에서 청력소실의 정도가 더 심하였고 보다 비전형적인 임상양상을 보였으며 늦은 나이에서 발견되었다.

이에 저자들은 아직까지 선천성 진주종의 발병기전이 명확히 밝혀지지는 않았지만 폐쇄형과 개방형의 선천성 중이 진주종의 발병 부위가 다르듯이 발병기전이 서로 다르지 않을까 하는 생각을 가지게 되었다. 어떤 한가지 발병기전에 의해 선천성 진주종이 발생하여 두 가지의 서로 다른 병리조직학적 형태로 분화된다고 생각할 수 도 있지만 서로 다른 발병기전에 의해 두 가지의 서로 다른 병리조직학적 형태를 가진 선천성 진주종이 발생 하게 된다고 생각하는 것이 더 타당하다고 사료된다. 앞 으로 보다 많은 증례분석을 통한 선천성 진주종의 병리 조직형태에 따른 발병기전을 밝히기 위해 지속적인 노 력이 필요하리라 생각된다. 


\section{결 론}

개방형의 선천성 중이 진주종은 대체로 중이강의 후상 방에서 기원하였으며 폐쇄형의 선천성 중이 진주종에 비해서 청력소실이 더 심하였고 보다 비전형적인 양상을 보였으며 늦은 나이에 발견되었다.

저자들은 본 연구를 통하여 폐쇄형과 개방형의 선천성 중이 진주종이 서로 다른 기전으로 생기는 것이 아닐까 하는 생각을 가지게 되었고 앞으로 선천성 진주종의 발 병기전을 밝히기 위한 지속적인 노력이 필요할 것으로 사료된다.

중심 단어 : 개방형 선천성 진주종 폐쇄형 선천성 진주 종. 발병기전.

\section{REFERENCES}

1) Park K, Chun YM, Lee DH, Koo SM. A review of seven congenital cholesteatoma of the middle ear. Korean J Otolaryngol 1996;39:382-90.

2) Kim JS, Chang SO, Lee KS, Lee DW, Kang JK, Noh KT. Clinical evaluation of congenital cholesteatoma. Korean J Otolaryngol 1995;38:195-204.

3) Friedberg J. Congenital cholesteatoma. Laryngoscope 1994;104 (Suppl 62):1-24.

4) McGill TJ, Merchant S, Healy GB, Friedman EM. Congenital cholesteatoma of the middle ear in children: A cli- nical and histopathological report. Laryngoscope 1991; 101:606-13.

5) Levenson MJ, Parisier SC, Chute P. A review of twenty congenital cholesteatomas of the middle ear in children. Otolaryngol Head Neck Surg 1986;94:560-7.

6) McDorald TJ, Cody DTR, Ryan RE. Congenital cholesteatoma of the ear. Ann Otol Rhinol Laryngol 1984;93: 637-40.

7) Sade J, Babiacki A, Pinkus G. The metaplastic and congenital origin of cholesteatoma. Acta Otolaryngol 1983;96: 119-29.

8) Aimi K. Role of the tympanic ring in the pathogenesis of congenital cholesteatoma. Laryngoscope 1983;93:1140-6.

9) Northrop C, Piza J, Eavey R. Histological observations of amniotic fluid cellular content in the ear of neonates and infants. Int J Pediatr Otol 1986;11:1113-27.

10) Michaels L. An epidermoid formation in the developing middle ear: Possible source of cholesteatoma. J Otolaryngol 1986;15:169-74.

11) Soderberg KC, Dornhoffer JL. Congenital cholesteatoma of the middle ear: Occurrence of an "open" lesion. Am J Otol 1998;19:37-41.

12) Derlacki EL, Clemis JD. Congenital cholesteatoma of the ear. Ann Otol Rhinol Laryngol 1965;74:706-27.

13) Levenson MJ, Michaels L, Parisier SC. Congenital cholesteatomas of the middle ear in children: Origin and management. Otolaryngol Clin North Am 1989;22:941-53.

14) Takeda E, Yabe T, Suzuki JI. Opentype congenital cholesteatoma. Adv Otorhinolaryngol 1997;51:29-34.

15) Michaels L. Origin of congenital cholesteatoma from a normally occuring epidermoid rest in the developing middle ear Int J Pediatr Otorhinolaryngol 1988:15:51-65.

16) Cohen D. Locations of primary cholesteatoma. Am J Otol 1987;8:61-5. 